\title{
Effects of climatic changes and anthropogenic activities on lake eutrophication in different ecoregions
}

\author{
X. Chuai $\cdot$ X. Chen $\cdot$ L. Yang $\cdot$ J. Zeng $\cdot$ \\ A. Miao $\cdot$ H. Zhao
}

Received: 13 March 2011/Revised: 8 August 2011/Accepted: 25 November 2011/Published online: 13 April 2012

(C) CEERS, IAU 2012

\begin{abstract}
Climatic changes and anthropogenic activities could affect nutrients' status significantly in the different lake ecosystems. Nutrients in Lake Hulun and Lake Taihu, two largest shallow cyanobacteria-blooming lakes in northern and southern China, respectively, were at eutrophicated levels in 2009. The concentrations of total nitrogen and total phosphorus were 3.346 and $2.250 \mathrm{mg} / \mathrm{L}$ as well as 0.435 and $0.062 \mathrm{mg} / \mathrm{L}$, respectively, in these two lakes with different causes of eutrophication. For Lake Hulun, it was the decreased amount of water as a result of the warming and drying climate that accounted for the abrupt increase of total nitrogen and total phosphorus levels through inspissation. In addition, the icebound effects, no outflows, low nutrients sequestration by the sediment and the reduction of aquatic productivity made the situation even worse. On the contrary, high population densities, the rapid development of agriculture and industry as well as urbanization have increased the nitrogen and phosphorus loads on Lake Taihu. Therefore, higher criteria of total nitrogen and total phosphorus should be applied in Lake Hulun given the difficulties in controlling climatic changes while much more rigorous standards should be established for Lake Taihu since the anthropogenic impacts on nutrient status are relatively easy to control.
\end{abstract}

X. Chuai $\cdot$ X. Chen $\cdot$ L. Yang $(\bowtie) \cdot$ J. Zeng $\cdot$ A. Miao

State Key Laboratory of Pollution Control and Resource Reuse,

School of the Environment, Nanjing University,

Nanjing 210046, China

e-mail: yangly@nju.edu.cn

H. Zhao

Weather Bureau of Hulun-Bier City, Hailar, Inner Mongolia 021008, China
Keywords Criteria $\cdot$ Nitrogen $\cdot$ Phosphorus . Sediment properties - Standard .

Water quality parameters

\section{Introduction}

Eutrophication of large shallow lakes have been drawing more and more attention in the past few decades, and it put critical challenges to the lake managers and limnologists who are trying to treat and remediate these eutrophicated water bodies (James et al. 2009; Kangur and Mols 2008; McCarthy et al. 2009; Maemets et al. 2010; Marotta et al. 2010; Song et al. 2010). These challenges stem largely from how to formulate the criteria and standard of nutrients for different lakes based on the various impact factors, such as characteristics of drainage basin, nutrients and biological variables and so on, were in need of comprehensive consideration (Chen 2009; Heiskary and Wilson 2008; Khemiri and Chenini 2009; Reckhow et al. 2005; Soranno et al. 2008; United States Environmental Protection Agency 2000). Among them, nutrients variable [nitrogen $(\mathrm{N})$ and phosphorus $(\mathrm{P})$ ] was the dominant one because too much $\mathrm{N}$ and $\mathrm{P}$ inputs could lead to the outbreak of nuisance, toxic cyanobacterial blooms (Anderson et al. 2002; Havens 2003; Le et al. 2010; Qin 2009; Xie 2008). In addition, other factors, such as climate changes, hydrological and geological conditions, anthropogenic activities could also affect the nutrient levels significantly (Jeppesen et al. 2003; Jones et al. 2008; Li et al. 2008; Song et al. 2010; Wang et al. 2005; Xue et al. 2003; Xu et al. 2009, 2010; Zhu et al. 2005; Zhao et al. 2007), which should thus be taken into consideration for the formulation of nutrients criteria and standard. Further research is required to measure the nutrient levels in the lake ecosystems and further examine 
Table 1 Comparison of parameters between Lake Hulun and Lake Taihu

\begin{tabular}{lll}
\hline Parameters & Lake Hulun & Lake Taihu \\
\hline Latitude and longitude & $48^{\circ} 30^{\prime} 40^{\prime \prime}-49^{\circ} 20^{\prime} 40^{\prime \prime} \mathrm{N}$ & $30^{\circ} 55^{\prime} 40^{\prime \prime}-31^{\circ} 32^{\prime} 58^{\prime \prime} \mathrm{N}$ \\
& $117^{\circ} 00^{\prime} 10^{\prime \prime}-117^{\circ} 41^{\prime} 40^{\prime \prime} \mathrm{E}$ & $119^{\circ} 52^{\prime} 32^{\prime \prime}-120^{\circ} 36^{\prime} 10^{\prime \prime} \mathrm{E}$ \\
Lake area $\left(\mathrm{km}^{2}\right)$ & $1,918.8(2006)$ & 2,338 \\
Total water storage (billion $\left.\mathrm{m}^{3}\right)$ & 13.85 & 4.43 \\
Average water depth $(\mathrm{m})$ & $2.45(2009)$ & 1.89 \\
Perennial mean temperature $\left({ }^{\circ} \mathrm{C}\right)$ & -0.1 & $15-17$ \\
Multiyear average precipitation $(\mathrm{mm})$ & 319 & $1,161.9$ \\
Multiyear average evaporation $(\mathrm{mm})$ & $1,400-1,900$ & 821.7 \\
Average TN load (t/year) & $2,359.6$ & $34,804.49$ \\
Average TP load (t/year) & 610.29 & $2,610.41$ \\
\hline
\end{tabular}

their underlying mechanisms. Lake Hulun, the first largest lake in northern China, used to be a bright pearl in Hulunbier Grassland (Li et al. 2008) where the Founding emperor of Yuan Dynasty (Genghis Khan) grew up. It located in $117^{\circ} 00^{\prime} 10^{\prime \prime} \mathrm{E}-117^{\circ} 41^{\prime} 40^{\prime \prime} \mathrm{E}, \quad 48^{\circ} 30^{\prime} 40^{\prime \prime} \mathrm{N}-49^{\circ} 20^{\prime} 40^{\prime \prime} \mathrm{N}$ (Table 1), and plays crucial roles in guarding ecological security of north China. However, cyanobacterial bloom due to high nutrients levels started to trouble it in the recent years (Li et al. 2008) which receives little attention since the impacts were not so widespread as that in Lake Taihu (James et al. 2009; Li et al. 2008; Qin et al. 2004a; Zhu et al. 2005). Extensive studies on Lake Taihu (the third largest lake in southern China) have been conducted by Chuai et al. (2011), James et al. (2009), McCarthy et al. (2007) and Zhu et al. (2008) recently.

McCarthy et al. (2007) investigated the $\mathrm{N}$ dynamics and the microbial food web structure during a summer cyanobacterial bloom in Lake Taihu and proposed that denitrification in Meiliang Bay affected the $\mathrm{N}$ dynamics in Lake Taihu significantly. Accordingly, $\mathrm{N}$ gradients from Liangxi River to the central lake were observed. Two years of monthly investigation and 1 month of daily investigation in Lake Taihu was carried out by Zhu et al. (2008). They found the high temporal differences of total phosphorus (TP) in the surface water. James et al. (2009) compared nutrients status in Lake Taihu (P. R. China) with those in Lake Okeechobee (USA). Both lakes suffered from serious cyanobacterial blooms. As TP concentrations in Meiliang Bay were always high in recent years, cyanobacterial bloom occurred frequently and seriously in this area according to Chuai et al. (2011). These indicated that cyanobacterial bloom was extremely serious in Lake Taihu, which was highly correlated to nutrients concentrations (Guo 2007; Pearl et al. 2011; Qin 2009; Xie 2008). Meanwhile, Pearl et al. (2011) proposed that the sustainability of freshwater ecosystems were threatened by harmful cyanobacterial blooms as an indicator of hypereutrophication. Cyanobacterial blooms could not only reduce dissolved oxygen (DO) contents and Secchi depth
(SD) values, but also could produce odor, heterotopic substances and microcystins, and thus do harm to other aquatic organisms, human health and the biogeochemical cycles of $\mathrm{N}$ and $\mathrm{P}$ (Havens 2008; Xie et al. 2005).

As mentioned above, both of these two lakes were suffering from cyanobacterial bloom, the main objective of this work is to: (1) investigate the $\mathrm{N}$ and $\mathrm{P}$ status in Lake Hulun (located in Inner Mongolia, China, Table 1) and Lake Taihu (located in Jiangsu Province, China, Table 1) by field investigation in 2009 and 2010; (2) reveal how natural factors (including atmospheric temperature, the drying and warming climate, monsoon, inflows and outflows) and anthropogenic activities (population densities, the production of agriculture and industry, urbanization) affected the $\mathrm{N}$ and $\mathrm{P}$ levels in these two lakes from 1991 to 2009; (3) illustrate how high nutrients levels and their contributing factors affected the formulation of nutrients criteria and standard in these two lakes and assess the influences of ecological differences on the lake management in different regions of China.

\section{Materials and methods}

\section{Selected lakes and sampling sites}

Lake Hulun, with an area of $1918.8 \mathrm{~km}^{2}$ (in 2006), is one of the largest lakes in the northeast of China and it has been suffering from eutrophication since 1980s due to its high levels of nutrients in the aquatic environment $(3.346 \mathrm{mg} / \mathrm{L}$ total nitrogen $(\mathrm{TN})$ and $0.435 \mathrm{mg} / \mathrm{L} \mathrm{TP}$, respectively; $\mathrm{Li}$ et al. 2008). It is located in Hunlunbier Grassland so that hay being flowed by wind is one of the most important nutrient sources (Li et al. 2008; Wang 2006; Zhao et al. 2007). Crulen River and Orshun River are the two main inflow rivers with decreasing water amount in recent years. The field observation of this study indicated that Orshun River had been in the state of zero inflow since 2009. Xinkai River used to be the main outflow of Lake Hulun, 
which, however, had become an inflow river to Lake Hulun in recent years as its water level has been declining recently (Li et al. 2008; Xue et al. 2003).

Lake Taihu, the third largest freshwater lake in southern China, has also been in a serious eutrophic status, suffering from cyanobacteria bloom in many lake regions, i.e., Meiliang Bay, due to the rapid industrial and agricultural development, high population densities and urbanization in the Taihu drainage (Bai et al. 2009; Qin et al. 2004a, b; Xie 2008; Xu et al. 2009). Furthermore, the amount of macrophyte in the east lake regions is so large that some indirect effects, such as "Jiaohuang" water, swamping, could also do harm to the lake to a great extent (Qin et al. 2004b). The inflow rivers with much higher nutrients levels and the outflow rivers with relatively lower nutrients levels are distributed in the northwest and southeast of Lake Taihu, where cyanobacteria- and macrophyte-dominated eutrophications were observed, respectively, in recent years (He et al. 2008; Qin et al. 2004b; Xie 2008; Zhu et al. 2005, 2008).

To measure the water quality, the mesh points method was taken to collect the water sample $(-50 \mathrm{~cm})$ and surface sediment samples $(0-10 \mathrm{~cm})$ in Lake Hulun (August and September 2009 and January 2010) and Lake Taihu (March, July and December in 2009), respectively (Fig. 1). The sampling intervals for these two lakes were dry season, level season and wet season, respectively, and different sampling periods were designed in this work in order to make good comparisons of their nutrients statuses because they were in two different climatic zones. There were two replicates at each site.

Analysis methods

Physiochemical parameters of water quality in Lake Hulun and Lake Taihu, such as temperature (Tem), electrical conductivity (EC), salinity, $\mathrm{pH}$, turbidity and $\mathrm{DO}$ were measured by Multi-Parameter Water Quality Instrument YSI6600V2 in situ water body of these two lakes, respectively. Secchi Plate was used to detect SD in the field. Meanwhile, 20-ml aliquot was collected from every sampling site and refrigerated for chlorophyll- $a$ (Chl- $a$ ) analysis later. For this purpose, the samples were filtered, ground, extracted by $90 \%$ acetone, centrifuged and absorbance was then measured with UV-Vis spectrophotometer (APHA 1995). The dissolved organic carbon (DOC) contents were analyzed by SHIMADZU TOC5000A in State Key Laboratory of Pollution Control and Resource Reuse, China. The TN, TP and total dissolved phosphorus (TDP) were determined by persulfate oxidation and spectrophotometry using a Shimadzu UV 2450 spectrophotometer (Jin and Tu 1990). After passing through $0.22-\mu \mathrm{m}$ mixed-fiber membrane, the aqueous nitrate nitrogen $\left(\mathrm{NO}_{3}{ }^{-}-\mathrm{N}\right)$, nitrite nitrogen $\left(\mathrm{NO}_{2}{ }^{-}-\mathrm{N}\right)$ and
Fig. 1 Map of Lake Hulun and Lake Taihu (Solid circles represent the sampling sites in these two lakes)

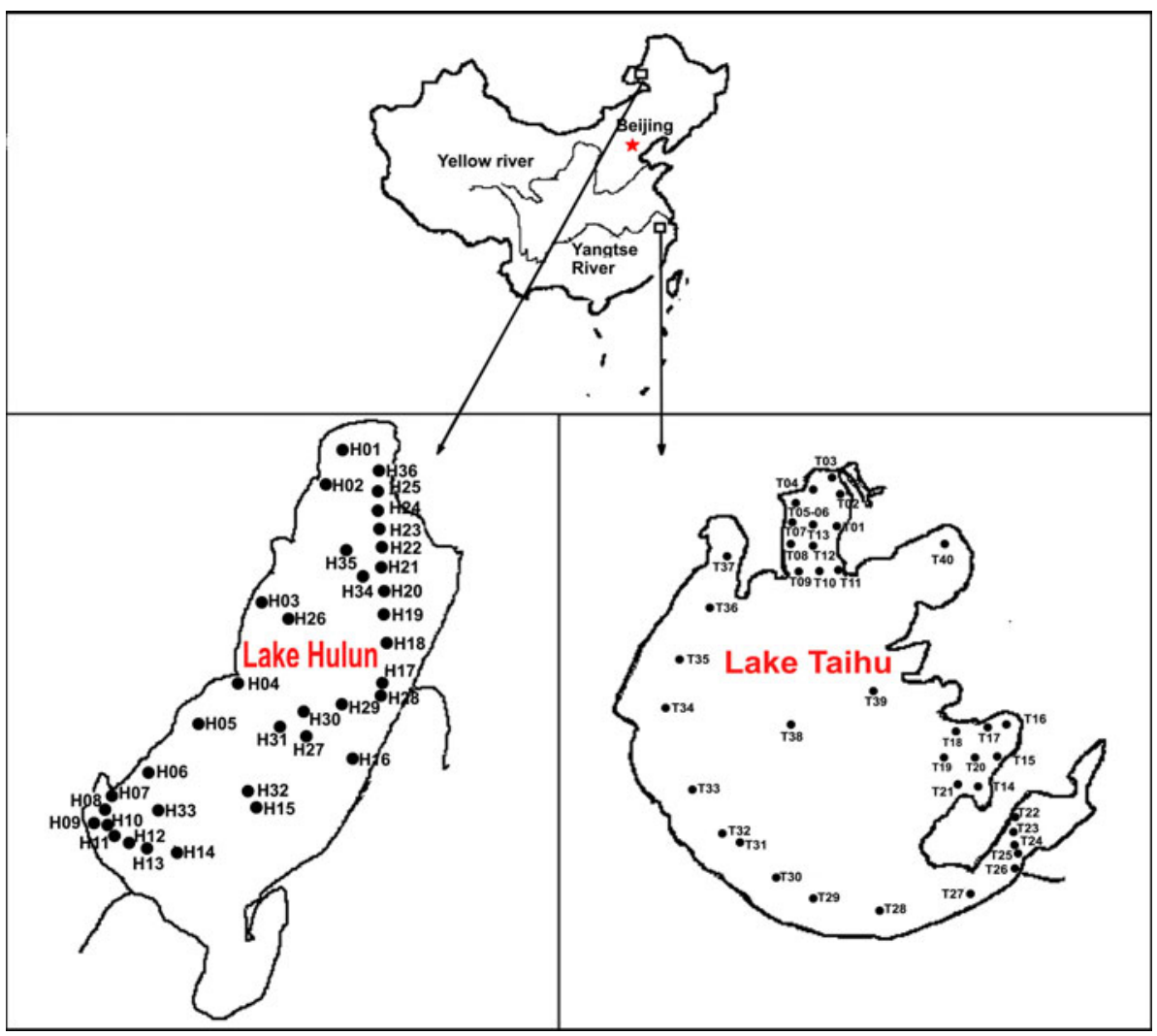


Table 2 Cited references

\begin{tabular}{lll}
\hline Parameters & Lake Hulun & Lake Taihu \\
\hline TN and TP (1991-2008) & $\begin{array}{c}\text { Han and Yang (2002); Li } \\
\text { et al. (2008) }\end{array}$ & $\begin{array}{c}\text { Water resources quality status bulletin for water body in province boundaries } \\
\text { of Lake Taihu catchment and all the southeast rivers } \\
\text { Huang and Xu (2009) }\end{array}$ \\
$\begin{array}{c}\text { Atmospheric temperature, rainfall } \\
\text { Inner Mongolia; Zhao } \\
\begin{array}{c}\text { Population, agricultural production } \\
\text { and industrial production }\end{array}\end{array}$ & $\begin{array}{c}\text { Web site of Hulunbier } \\
\text { Government (present) }\end{array}$ & $\begin{array}{c}\text { Statistical Bulletin of National Economic and social development in Suzhou, } \\
\text { Wuxi, Changzhou and Huzhou City (1991-2009); Liu et al. (2006) }\end{array}$ \\
$\begin{array}{ll}\text { Aquatic production (1998-2007) } \\
\text { Li et al. (2008) }\end{array}$ & \\
\hline
\end{tabular}

ammonium nitrogen $\left(\mathrm{NH}_{4}{ }^{+}-\mathrm{N}\right)$ concentrations were detected by UV-spectrophotometry, $N$-(1-naghthyl)-1,2diaminoethane dihydrochloride spectrophotometry and Nessler's Reagent Spectrophotometry (Environmental Protection Administration of China < Monitoring method of water and wastewater $>$ editor committee 2002). Another $10-\mathrm{ml} \quad 0.45-\mu \mathrm{m}$ mixed-fiber membrane filtered aliquots were sent to Nanjing Institute of Geography and Limnology for dissolved inorganic phosphorus (DIP) analysis, which was detected by skalar flow-injection analyzer. Error estimates were determined as the differences compared the detective ones with average value of triplicates.

The N, P and various metal contents in the air-dried sediments were measured by Vario Micro elementary analyzer and ARL 9800 X-ray fluorescence spectrometer. The sediment surface was further probed using a S-3400N II Scanning Electron Microscope. For all the sediment samples, triplicates were analyzed and the data were reported as the average in this study.

The evaluation of trophic state in Lake Hulun and Lake Taihu

The trophic state indexes (TSI) developed by Carlson (1977) and Jin and Tu (1990) were taken to assess the trophic status in Lake Hulun and Lake Taihu from 2004 to 2009. The sources of the historical data for TN, TP, atmospheric temperature, rainfall, evaporation, population density, agricultural, industrial and aquatic production in Lake Hulun and Lake Taihu were listed in Table 2. The TSI is composed of Chl- $a\left(\mathrm{mg} \mathrm{m}^{-3}\right)$, TN (mg/L), TP $(\mathrm{mg} / \mathrm{L}), \mathrm{SD}(\mathrm{m})$ and chemical oxygen demand (COD, $\mathrm{mg} / \mathrm{L})$. The combining or single TSI were calculated as follows (1-6):

$\operatorname{TSI}\left(\sum\right)=\sum W_{i} \times \operatorname{TSI}(i)$

where $i=\mathrm{Chl}-a$, TN, TP, SD and COD, respectively; $W_{i}=R_{i}^{2} / \sum R_{i}^{2}, R_{i}$ represent the correlation coefficients of Chl- $a$, TN, TP, SD and COD, respectively.

$\operatorname{TSI}($ Chl- $a)=10 \times(2.500+1.086 \times \operatorname{lnChl}-a)$
TSI $(\mathrm{TN})=10 \times(5.453+1.694 \times \ln \mathrm{TN})$

TSI $(\mathrm{TP})=10 \times(9.436+1.624 \times \ln \mathrm{TP})$

TSI $(\mathrm{SD})=10 \times(5.118-1.940 \times \operatorname{lnSD})$

TSI $(\mathrm{COD})=10 \times(0.109+2.661 \times \operatorname{lnCOD})$.

The formulation of criteria and standard

The criteria for TN and TP in both Lake Hulun and Lake Taihu were established through the analysis of historical data, determination of boundary conditions and application of Carlson's TSI based on the Nutrient Criteria Technical Guidance Manual-Lakes and Reservoirs (2000). Finally, the corresponding TN and TP standards were also established by comprehensive consideration of climatic conditions, hydrological conditions, geological conditions and anthropogenic activities.

\section{Statistical analysis}

The standard deviations of various parameters in both of these two lakes were calculated using Microsoft excel 2007. The correlations among TN, TP, Tem, rainfall, evaporation, lake area, population density, agricultural and industrial productions in both of these two lakes were analyzed with SPSS 17.0. The differences in nutrients concentrations between Lake Hulun and Lake Taihu were also analyzed with correlation analysis using SPSS 17.0.

Results and discussion

Harmful cyanobacterial blooms in global eutrophicated lakes changed their utilization modes as drinking water sources, fisheries and recreational purposes, and further threatened the sustainability of the freshwater ecosystems (Pearl et al. 2011). Increasingly, high nutrient ( $\mathrm{N}$ and $\mathrm{P}$ ) levels are one of the crucial factors for the outbreak of cyanobacterial blooms (Guo 2007). Therefore, both N and P levels of Lake Hulun and Lake Taihu in 2009 were investigated, and the potential impact factors, including natural and anthropogenic factors, were further discussed. 
Fig. 2 Variations of TN (a), $\mathrm{NO}_{3}{ }^{-}-\mathrm{N}(\mathbf{b}), \mathrm{NO}_{2}{ }^{-}-\mathrm{N}(\mathbf{c})$ and $\mathrm{NH}_{4}{ }^{+}-\mathrm{N}(\mathbf{d})$ concentrations in Lake Hulun $(\mathrm{H})$ and Lake Taihu (T) from 2009 to 2010
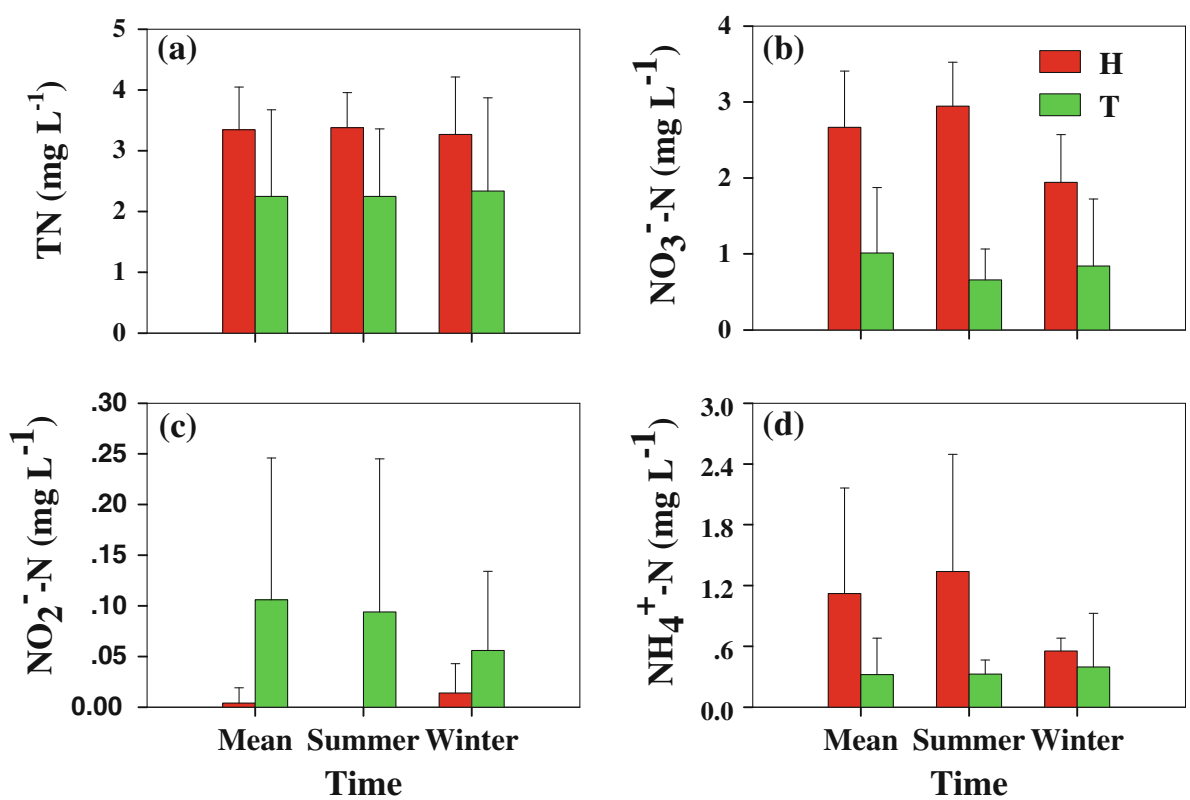

Nutrient status

Nutrient status is closed to sustainability of the lake ecosystems, and $\mathrm{N}$ (including $\mathrm{TN}, \mathrm{NO}_{3}{ }^{-}-\mathrm{N}, \mathrm{NO}_{2}{ }^{-}-\mathrm{N}$ and $\mathrm{NH}_{4}{ }^{+}-$ $\mathrm{N})$ is the crucial element for aquatic organisms. The mean concentrations of $\mathrm{TN}(3.346 \pm 0.700 \mathrm{mg} / \mathrm{L}), \mathrm{NO}_{3}{ }^{-} \mathrm{N}$ $(2.666 \pm 0.740 \mathrm{mg} / \mathrm{L})$, and $\mathrm{NH}_{4}{ }^{+}-\mathrm{N}(1.120 \pm 1.143 \mathrm{mg} / \mathrm{L})$ in Lake Hulun in 2009 were much higher than that of TN $(2.250 \pm 1.423 \mathrm{mg} / \mathrm{L}), \mathrm{NO}_{3}{ }^{-}-\mathrm{N}(1.012 \pm 0.862 \mathrm{mg} / \mathrm{L})$ and $\mathrm{NH}_{4}{ }^{+} \mathrm{-N}(0.322 \pm 0.359 \mathrm{mg} / \mathrm{L})$ in Lake Taihu (Fig. 2a, b, d). However, it was obvious that the aqueous $\mathrm{NO}_{2}{ }^{-}-\mathrm{N}$ concentrations in Lake Taihu $(0.106 \pm 0.140 \mathrm{mg} / \mathrm{L})$ were much higher than that in Lake Hulun $(0.004 \pm 0.015 \mathrm{mg} / \mathrm{L})$ in 2009 (Fig. 2c). In addition, no significant spatial-temporal difference for all forms of $\mathrm{N}$ concentrations was observed in Lake Hulun $(p>0.05)$ in contrast to the significant variations found in Lake Taihu $(p<0.05)$. The aqueous $\mathrm{NO}_{3}{ }^{-}-\mathrm{N}$ and $\mathrm{NH}_{4}{ }^{+}-\mathrm{N}$ concentrations in Lake Hulun were much higher in summer than that in winter while the trends got reserved in Lake Taihu. Conversely, the aqueous $\mathrm{NO}_{2}{ }^{-}-\mathrm{N}$ concentrations in Lake Taihu were much higher in summer than that in winter while no significant amount of $\mathrm{NO}_{2}{ }^{-}-\mathrm{N}$ was detected in any of the sampling sites of Lake Hulun in summer (Fig. 2c).

The $\mathrm{P}$ (with the forms of TP, TDP and DIP) is also an essential biogenic element in the lake ecosystems. It was found in the present study in 2009 that the aqueous TP, with the mean concentration of $0.435 \pm 0.060 \mathrm{mg} / \mathrm{L}$, were much higher in Lake Hulun than that in Lake Taihu (Fig. 3), and TP concentration was much higher in winter than that in summer for Lake Hulun but lower in winter for Lake Taihu (Fig. 3a). Further more, significant spatial differences in the aqueous TP concentrations were observed in Lake Taihu whereas TP was evenly distributed in Lake Hulun $(p>0.05)$. Similar change trends of TDP and DIP to that of TP were observed in both lakes (Fig. 3b, c). Therefore, nutrients levels in water bodies of Lake Hulun are much higher than that of Lake Taihu.

Obviously, the aqueous TN and TP concentrations in Lake Hulun were about 1.5- and 7.0-folds of those in Lake Taihu in 2009, respectively. However, reverse trends were observed for the TSI values of these two lakes especially in summer when severe outbreak of cyanobacterial bloom occurred in Lake Taihu and the outbreak of cyanobacterial bloom was much smaller and shorter in Lake Hulun (the TSI values of these two lakes in 2009 were 68.65 and 56.47, respectively, Table 3). High nutrients levels were found in Lake Hulun but high Chl- $a$ contents occurred in Lake Taihu. Nevertheless, the TSI values in both lakes ranged from 56.47 to 68.65 , as comparable to that in Lake Okeechobee, USA from 1999 to 2004 (TSI = 57.54, James et al. 2009) and Lake Kasumigaura, Japan from 2001 to 2006 (TSI $=64.22$ ). Further research was thus required to investigate the underlying mechanisms of the eutrophication, especially the causes of high $\mathrm{N}$ and $\mathrm{P}$ concentrations, in both lakes (Guo et al. 2004; Guo 2007; Li et al. 2008; Qin et al. 2004a, b, 2007; Xie 2008; Xu et al. 2009).

\section{Effects of climate and its changes}

The climatic factors, such as atmospheric temperature, rainfall/snowfall, and evaporation influence $\mathrm{N}$ and $\mathrm{P}$ compositions and concentrations in the aquatic environment (Li et al. 2008; Qin et al. 2004b; Zhao et al. 2007). 

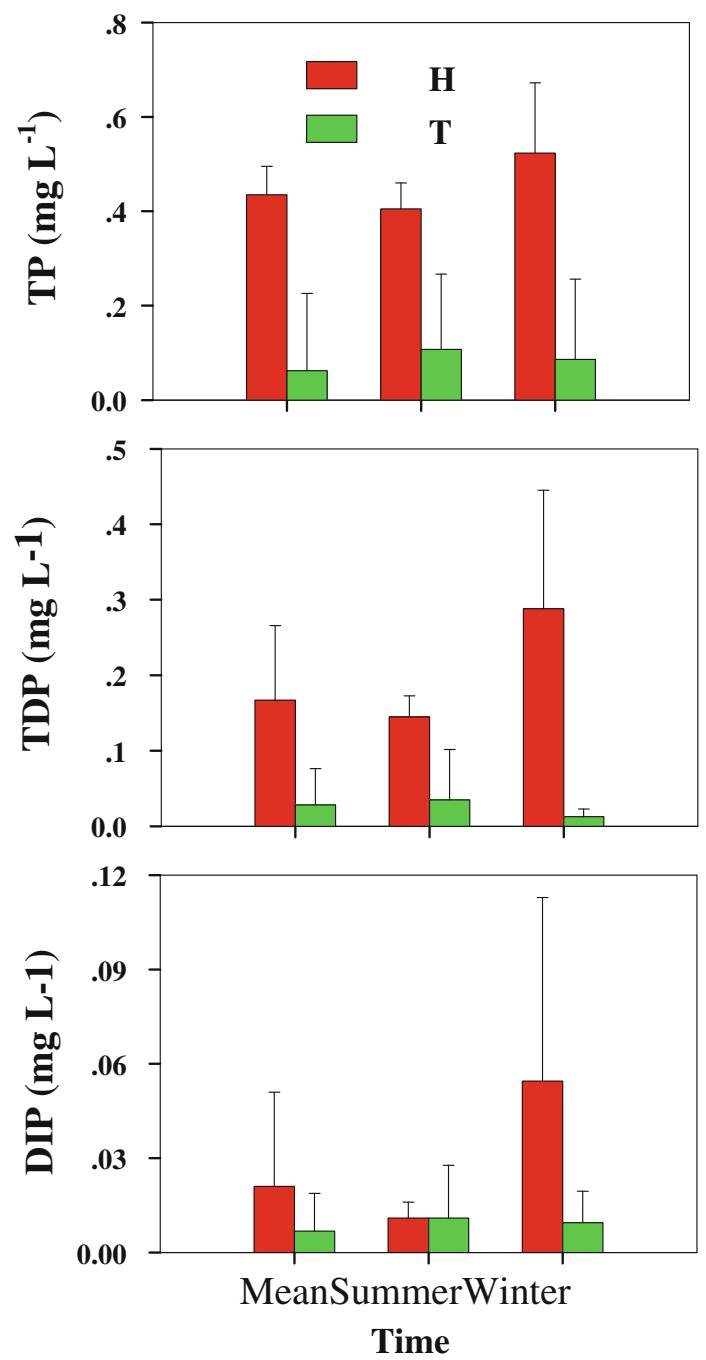

Fig. 3 Variations of TP (a), TDP (b) and DIP (c) concentrations in Lake Hulun (H) and Lake Taihu (T) from 2009 to 2010

Atmospheric temperature, as one of most important factors, could greatly change the biological activities and further the nutrient levels in lakes (Yuan et al. 2009; Zhao et al. 2011). For Lake Hulun, the concentrations of $\mathrm{TN}, \mathrm{NO}_{3}{ }^{-}-\mathrm{N}, \mathrm{NH}_{4}{ }^{+}-$ $\mathrm{N}, \mathrm{TP}$, TDP and DIP were extremely high and cyanobacterial bloom appeared (the highest cyanobacterial density was $3.14 \times 10^{8}$ cell/L) in a short period due to the relative higher temperature in summer $\left(12.2^{\circ} \mathrm{C}\right)$. Nevertheless, higher DOC contents in Lake Hulun indicated that the activities of microorganism were relative lower than that in Lake Taihu (Table 4). On the other hand, much higher N and P levels in Lake Hulun were observed in winter due to inspissation induced by the long-term icebound effects (about 180 days), i.e., the aqueous nutrients concentrations were concentrated to a great extent, with inspissation coefficient ranging from 1.167 to 1.570 in January of 2010 (Table 5). Contrastively, it was the combinative effects of decomposition and denitrification in cyanobacterial-dominated lake regions that resulted in the low $\mathrm{NO}_{3}{ }^{-}-\mathrm{N}$ and $\mathrm{NH}_{4}{ }^{+}-\mathrm{N}$ levels in summer for Lake Taihu (Asaeda et al. 2000; Mahmood et al. 2009; Tuomainen et al. 2003) (Fig. 2). The higher primary productivity in Lake Taihu than that in Lake Hulun due to their Tem differences (Fig. 4) since higher energy would be captured by the lake ecosystems when atmospheric temperature was higher (Chakrabarty and Das 2006).

Monsoon, as another climatic factor, also affects the nutrients levels in these two lakes. A large amount of $\mathrm{N}$ $(18.56 \%)$ and $\mathrm{P}(36.04 \%)$ flowing into Lake Hulun were originated from dry deposition of hay (Wang 2006) by the northwest monsoon (about $4.2 \mathrm{~m} / \mathrm{s}$ of the mean wind speed). Although there were southeast and northwest monsoon in summer and winter, respectively, the dry deposition accounted for only $5.52 \%$ of $\mathrm{N}$ and $7.61 \% \mathrm{P}$ sources in Lake Taihu during 2002-2003 (Zhai et al. 2009). Furthermore, the warming and drying of climate in Hulunbier Grassland led to the increase of atmospheric temperature and lake water evaporation, the decrease of rainfall/snowfall, and the decrease of the lake areas and the decline of water levels in Lake Hulun, and further the enhancement of $\mathrm{N}$ and $\mathrm{P}$ due to inspissation. The aqueous $\mathrm{TN}$ and TP concentrations increased from 1.08 and $0.048 \mathrm{mg} / \mathrm{L}$ in 1994 to 2.31 and $0.176 \mathrm{mg} / \mathrm{L}$ in 2006 when the lake area decreased from $2,316.3$ to $1,920.0 \mathrm{~km}^{2}$ and water level declined from 545.0 to $541.9 \mathrm{~m}$ (height above sea level) in Lake Hulun (Fig. 5). Negative correlation between aqueous nutrients (TN and TP) levels and lake

Table 3 The TSI values in Lake Hulun (H) and Lake Taihu (T), respectively, in 2004-2009

\begin{tabular}{|c|c|c|c|c|c|c|c|c|c|c|c|c|}
\hline \multirow[t]{2}{*}{ Items } & \multicolumn{2}{|c|}{ TSI (Chl- $a)$} & \multicolumn{2}{|c|}{ TSI (TN) } & \multicolumn{2}{|c|}{ TSI (TP) } & \multicolumn{2}{|c|}{ TSI (SD) } & \multicolumn{2}{|c|}{ TSI (Imn) } & \multicolumn{2}{|c|}{ TSI $\left(\sum\right)$} \\
\hline & $\mathrm{H}$ & $\mathrm{T}$ & $\mathrm{H}$ & $\mathrm{T}$ & $\mathrm{H}$ & $\mathrm{T}$ & $\mathrm{H}$ & $\mathrm{T}$ & $\mathrm{H}$ & $\mathrm{T}$ & $\mathrm{H}$ & $\mathrm{T}$ \\
\hline 2004 & 40.84 & 59.55 & 61.51 & 70.78 & 65.00 & 53.34 & 76.58 & 73.29 & 68.51 & 44.02 & 57.20 & 59.63 \\
\hline 2005 & 40.59 & 61.27 & 64.30 & 69.92 & 65.77 & 52.93 & 75.88 & 74.54 & 72.06 & 44.30 & 58.62 & 60.03 \\
\hline 2006 & 47.58 & 67.19 & 68.71 & 72.27 & 66.15 & 56.47 & 77.31 & 78.07 & 85.99 & 47.93 & 64.60 & 63.97 \\
\hline 2007 & 44.46 & 59.10 & 67.58 & 69.00 & 70.91 & 52.29 & 85.56 & 75.88 & 76.79 & 44.43 & 62.91 & 59.30 \\
\hline 2008 & 48.75 & 60.27 & 71.85 & 69.50 & 77.77 & 51.63 & 80.55 & 77.31 & 77.71 & 40.57 & 66.84 & 59.10 \\
\hline 2009 & 48.98 & 57.38 & 74.99 & 68.27 & 80.84 & 49.20 & 78.87 & 72.69 & 79.50 & 37.87 & 68.65 & 56.47 \\
\hline
\end{tabular}


Table 4 Water quality parameters in Lake Hulun and Lake Taihu in 2009 and 2010

\begin{tabular}{lcccccc}
\hline ID & HA & TA & HS & TS & HW & TW \\
\hline pH & $8.99 \pm 0.18$ & $8.29 \pm 0.28$ & $8.95 \pm 0.15$ & $8.560 \pm 0.26$ & $9.01 \pm 0.33$ & $8.09 \pm 0.20$ \\
DO $(\mathrm{mg} / \mathrm{L})$ & - & $10.81 \pm 1.74$ & $10.25 \pm 2.14$ & $8.12 \pm 0.73$ & - & $11.64 \pm 1.17$ \\
EC $(\mathrm{ms} / \mathrm{cm})$ & $3.554 \pm 0.096$ & $0.413 \pm 0.112$ & $3.135 \pm 0.065$ & $0.557 \pm 0.031$ & $3.867 \pm 0.108$ & $0.338 \pm 0.084$ \\
Salinity $(\%)$ & $1.51 \pm 0.21$ & $0.25 \pm 0.04$ & $1.42 \pm 0.12$ & $0.24 \pm 0.02$ & $1.59 \pm 0.25$ & $0.25 \pm 0.06$ \\
Turbidity (NTU) & $33.6 \pm 8.0$ & $48.7 \pm 37.8$ & $95.6 \pm 12.0$ & $10.1 \pm 10.5$ & $14.3 \pm 4.9$ & $61.2 \pm 37.9$ \\
Chl- $a(\mu \mathrm{g} / \mathrm{L})$ & $11.25 \pm 3.56$ & $19.71 \pm 9.38$ & $19.01 \pm 8.90$ & $26.73 \pm 13.17$ & $6.75 \pm 2.46$ & $11.02 \pm 2.18$ \\
DOC $(\mathrm{mg} / \mathrm{L})$ & $54.28 \pm 17.18$ & $9.31 \pm 4.43$ & $58.87 \pm 5.57$ & $6.97 \pm 3.43$ & $53.05 \pm 19.33$ & $17.00 \pm 3.36$ \\
\hline
\end{tabular}

Table 5 Inspissation coefficients of nutrients during the icebound periods in Lake Hulun

\begin{tabular}{lllll}
\hline Items & $C_{\text {aqueous }}$ & $C_{\text {ice }}$ & $C$ & $\eta$ \\
\hline $\mathrm{TN}$ & 3.269 & 1.058 & 2.532 & 1.570 \\
$\mathrm{NO}_{3}{ }^{-}-\mathrm{N}$ & 1.941 & 0.178 & 1.353 & 1.523 \\
$\mathrm{NO}_{2}{ }^{-}-\mathrm{N}$ & 0.014 & 0.008 & 0.012 & 1.167 \\
$\mathrm{NH}_{4}{ }^{-}-\mathrm{N}$ & 0.553 & 0.107 & 0.404 & 1.369 \\
$\mathrm{TP}$ & 0.523 & 0.235 & 0.427 & 1.225 \\
$\mathrm{TDP}$ & 0.288 & 0.095 & 0.224 & 1.286 \\
DIP & 0.157 & 0.019 & 0.111 & 1.414 \\
\hline
\end{tabular}
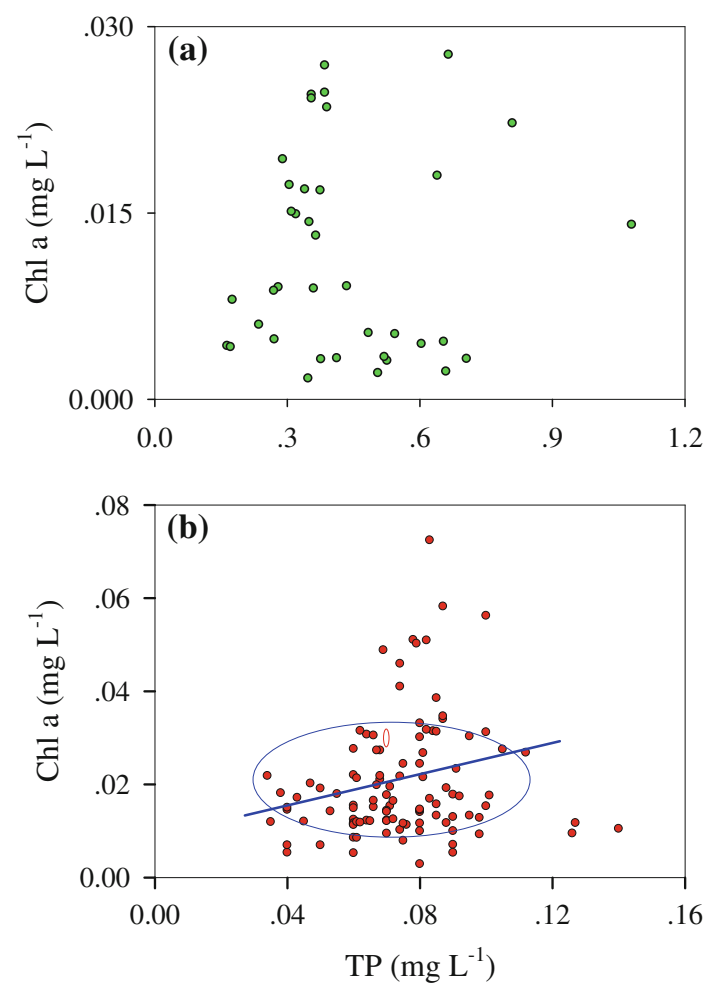

Fig. 4 The response of Chl- $a$ contents to TP levels in Lake Hulun (a) and Lake Taihu (b)

areas were observed from 1993 to $2006(p<0.05$, Table 6). In addition, the inspissation of water body made its $\mathrm{pH}$ increase from $\mathrm{pH} 8.71$ in 1991 to $\mathrm{pH} 9.05$ in 2009
(Table 4) and salinity rise from $0.78 \%$ in 1962 to $1.51 \%$ in 2009 (Table 4). Conversely, the lake area and water depth of Lake Taihu were relative stable, with the values of $2,338 \mathrm{~km}^{2}$ and $3.00-3.12 \mathrm{~m}$ (height above sea level) respectively, suggesting that the influences of lake area and water depth on its concentrations of nutrients were negligible. All changes of these climatic factors could provide a good explanation why the aqueous $\mathrm{N}$ and $\mathrm{P}$ were much higher in Lake Hulun than those in Lake Taihu (Fig. 2, Fig. 3).

Effects of nutrients input from inflows and output from outflows

The dynamics of nutrient inputs and outputs could affect the compositions and concentrations of nutrients in lake ecosystems. In Lake Hulun, water input decrease could substantially result in the shrink of lake areas and the decline of water levels (i. e., the water volumes of Crulen River that flowed into Lake Hulun decreased from 1 billion $\mathrm{m}^{3}$ in 1985 to 39 million $\mathrm{m}^{3}$ in 2007 and the water quantity of Orshun River decreased from 1.190 billion $\mathrm{m}^{3}$ in 1991 to $0 \mathrm{~m}^{3}$ in 2009; $\mathrm{Li}$ et al. 2008). Meanwhile, nutrients levels in the input rivers were much higher in 2009 (i.e., TN and TP concentrations were 3.960 and $1.111 \mathrm{mg} / \mathrm{L}$ in Crulen River, as measured in 2009) than that in 1980s, so the aqueous nutrients concentrations increased in Lake Hulun since no significantly decrease trends for $\mathrm{N}$ and $\mathrm{P}$ inputs from inflows. The TN and TP concentrations in the inflows of Lake Taihu were extremely high, with the maximum, 

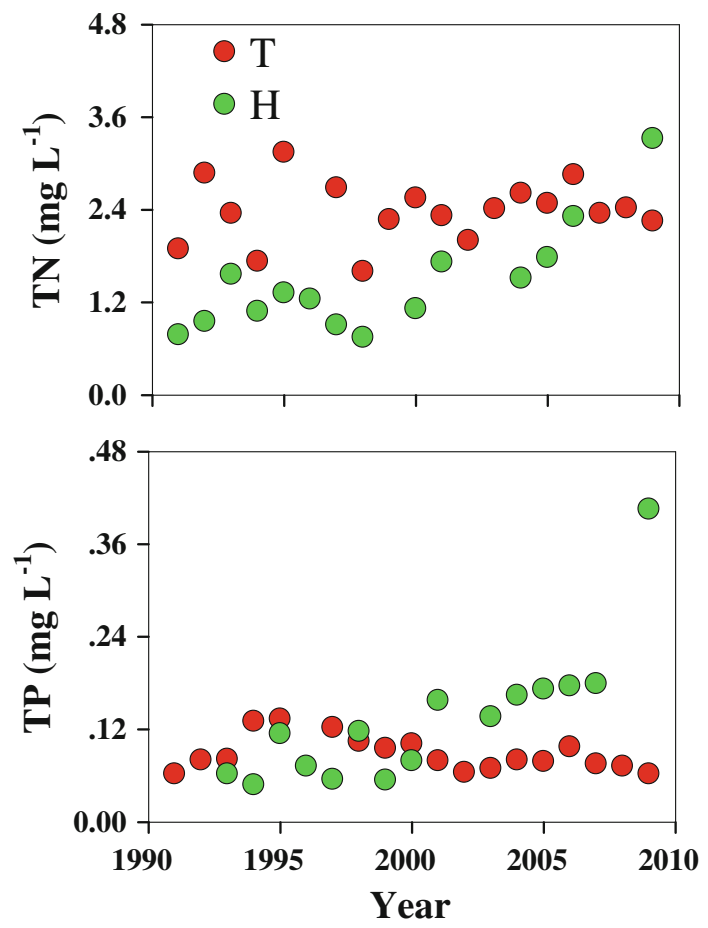

Fig. 5 Multiyear changes of aqueous $\mathrm{TN}$ and TP concentrations in Lake Hulun (H) and Lake Taihu (T)

minimum and mean $\mathrm{TN}$ concentrations of $11.278,2.541$ and $6.344 \mathrm{mg} / \mathrm{L}$, respectively, and the maximum, minimum and mean TP concentrations were $0.718,0.198$ and $0.406 \mathrm{mg} / \mathrm{L}$, respectively, as measured in 2009 and 2010. The huge nutrient inputs accelerated the eutrophication of Lake Taihu.

On the other hand, nutrients output could also affect $\mathrm{N}$ and $\mathrm{P}$ levels in lake water body to a great extent. No outflow was observed for Lake Hulun in recent years ( $\mathrm{Li}$ et al. 2008) since the water levels decreased sharply, namely, outflow could not export the nutrient anymore. However, the nutrient export from the outflow of Lake Taihu was much larger. The maximum, minimum and average TN concentrations in outflows were 8.802, 2.148 and
$4.183 \mathrm{mg} / \mathrm{L}$ respectively, and the maximum, minimum and average TP concentrations were 0.904, 0.169 and $0.401 \mathrm{mg} / \mathrm{L}$, respectively, in 2009 and 2010. Therefore, nutrients outputs from outflows could reduce much larger amount of $\mathrm{N}$ and $\mathrm{P}$ from water ecosystem in Lake Taihu than that in Lake Hulun.

Effects of aquatic production

The aquatic production could also play essential roles in cutting down the $\mathrm{N}$ and $\mathrm{P}$ levels in both Lake Hulun and Lake Taihu. For Lake Hulun, the production of aquatic products decreased sharply (from 15,907.7 t/a in 2002 to $5,349.3 \mathrm{t} / \mathrm{a}$ in 2007). Therefore, approximately $275.8 \mathrm{t} \mathrm{N}$ and $53.6 \mathrm{t} \mathrm{P}$ were retained in the lake owing to the reduction of aquatic products. For Lake Taihu, with the steady increase of fish production in recent years, the removal of $\mathrm{N}$ and $\mathrm{P}$ also increased steadily (Fig. 6). Therefore, the aquaculture industry accounted for the reduction of $\mathrm{N}$ and $\mathrm{P}$ more significantly in Lake Taihu while it play less and less roles in the removal of $\mathrm{N}$ and $\mathrm{P}$ from Lake Hulun.

Effects of the sediment properties

The sediment properties also had a significant effect on the nutrients status in Lake Hulun and Lake Taihu. The SEM analysis of sediment from both lakes revealed a higher adsorption capacity (i.e., more reactive sites) for the sediment from Lake Taihu (Fig. 7). The high Fe and Al oxides contents as found in the sediments from Lake Taihu could improve their $\mathrm{N}$ and $\mathrm{P}$ accommodation capacities ( $\mathrm{Li}$ et al. 2006; Wang et al. 2005; Zhou et al. 2005). Therefore, lower $\mathrm{N}$ and $\mathrm{P}$ contents were observed in sediment of Lake Hulun (3.630 and $0.306 \mathrm{mg} / \mathrm{g}$, respectively) than those in sediment of Lake Taihu (6.000 and $0.768 \mathrm{mg} / \mathrm{g}$, respectively) (Table 7). Furthermore, the prior lab experiments demonstrated that the maximum amount of P-adsorption on the sediment from Lake Hulun was only $25.9 \mu \mathrm{g} / \mathrm{g}$ at $25^{\circ} \mathrm{C}$
Table 6 The correlations between TN, TP and natural as well as social factors
$* p<0.05$

$* * p<0.01$

\begin{tabular}{lccccc}
\hline Items & \multicolumn{2}{l}{ Lake Hulun } & & \multicolumn{2}{l}{ Lake Taihu } \\
\cline { 2 - 3 } \cline { 5 - 5 } & TN & & & TN & TP \\
\hline $\mathrm{TN}$ & 1 & $0.565^{*}$ & & 1 & 0.154 \\
$\mathrm{TP}$ & $0.565^{*}$ & 1 & 0.154 & 1 \\
Temperature & 0.013 & 0.235 & & -0.321 & -0.044 \\
Rainfall & -0.377 & $-0.676^{*}$ & & 0.684 & 0.482 \\
Evaporation & 0.119 & -0.502 & & 0.111 & 0.035 \\
Area & $-0.668^{*}$ & $-0.876^{* *}$ & & 0.155 & 0.231 \\
Population density & 0.065 & 0.037 & & 0.181 & 0.316 \\
Agricultural production & 0.023 & 0.068 & & 0.087 & 0.184 \\
Industrial production & 0.082 & 0.103 & 0.067 & 0.169 \\
\hline
\end{tabular}




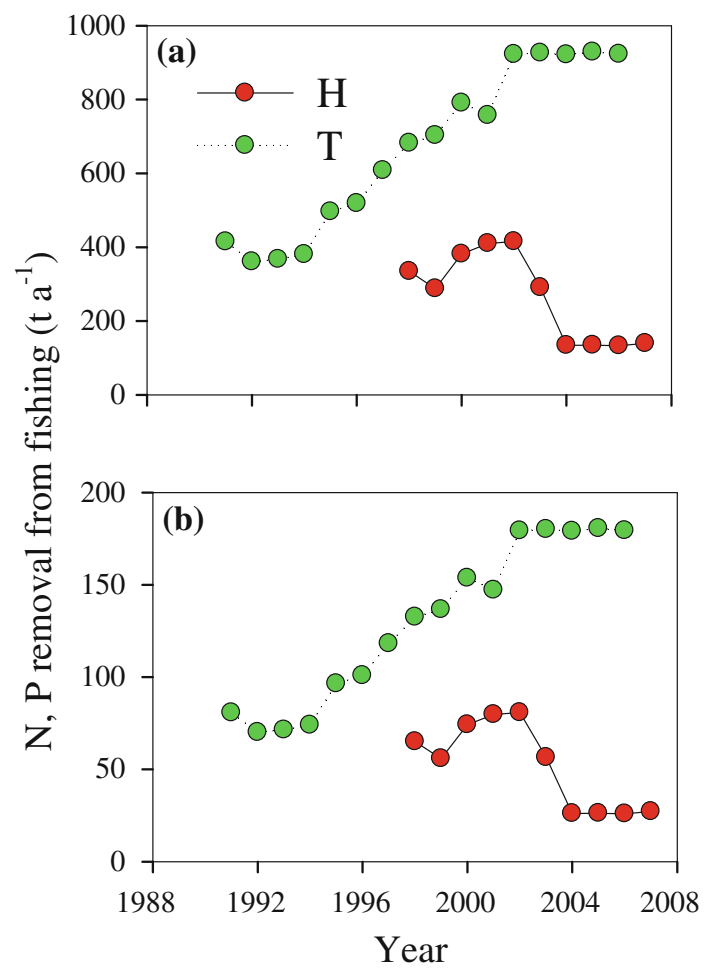

Fig. 6 The removal of $\mathrm{N}$ (a) and $\mathrm{P}$ (b) via to the catch of aquatic products in multiyears

with the initial aqueous $\mathrm{P}$ concentration of $0.500 \mathrm{mg} / \mathrm{L}$. However, the higher adsorption capacity was observed in Lake Taihu, with the maximum adsorption amount of $526.32 \mu \mathrm{g} / \mathrm{g}$. These findings were consistent with those of Wang et al. (2005).

\section{Effects of anthropogenic activities}

Human activities also affected the nutrients status in the aquatic ecosystems by increasing the nutrients inputs (Xu et al. 2009). The population density in Hulunbier Grassland around Lake Hulun was less than 11 person $/ \mathrm{km}^{2}$ in 2008 and their residence was more than $8 \mathrm{~km}$ far from Lake Hulun ( $\mathrm{Li}$ et al. 2008). The grass production was only 63.27 billions as reported by local statistical bureau in Hulunbier in 2008. As result of the low population densities, relative underdeveloped economics and the extremely scarce agriculture, the influences of anthropogenic activities on the nutrients status were very little. In contrast, the $\mathrm{N}$ and $\mathrm{P}$ status in Lake Taihu was affected by anthropogenic activities much more significantly. The industrial and agricultural production of Taihu Delta increased from 164.75 billion RMB and 199.48 billion RMB in 1990 to 4,246.59 billion RMB and 609.41 billion RMB in 2009, respectively. The population density was 1,172 person $/ \mathrm{km}^{2}$ in the Taihu drainage in 2006. Although no good correlations were observed between nutrients
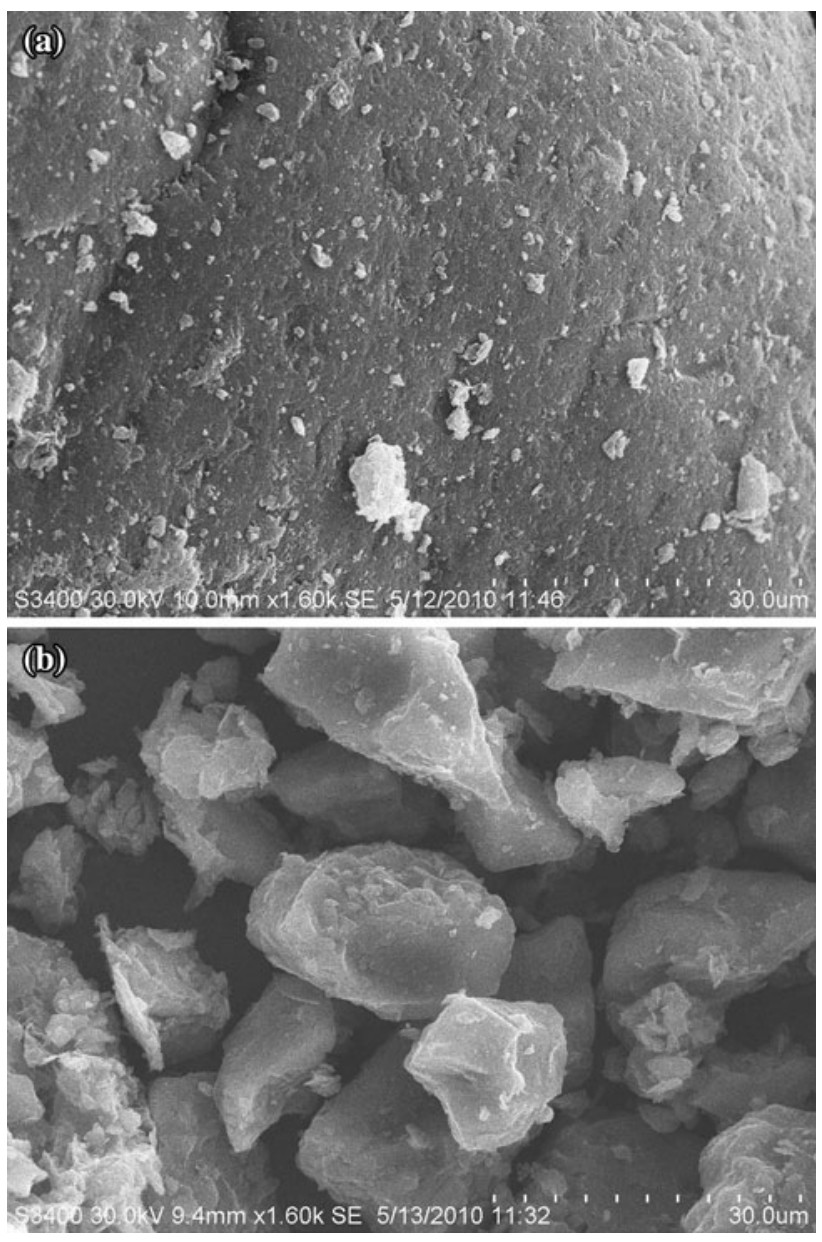

Fig. 7 SEM images of the sediments from Lake Hulun (a) and Lake Taihu (b)

levels (TN and TP) and anthropogenic activities (population density, the agricultural and industrial production) from 1987 to 2009, the facts that the rapid industrial and agricultural development, high population densities as well as urbanization of the Taihu drainage (Wuxi City, Changzhou City and Suzhou City were the developed cities in China) put heavy nutrients loads to Lake Taihu (Table 1). Therefore, it was anthropogenic activities other than natural factors that significantly affected the compositions and concentrations of nutrients in Lake Taihu. Furthermore, the anthropogenic activities could also influence the annual variations of $\mathrm{TN}$ and $\mathrm{TP}$ in Lake Taihu (Fig. 5). A series of anthropogenic actions, such as dredging, salvage of cyanobacteria, external nutrition control, water transfer from Yangtze River into Lake Taihu and so on (Hu et al. 2008; Qin et al. 2004b), also change the aqueous nutrients levels in Lake Taihu. For instance, the TN levels observed from the literatures were relatively stable in Lake Taihu in 1991-2009 while the change trends of TP showed a double-peak (with the 
Table 7 Physical and chemical characteristics of the sediments studied (\%)

\begin{tabular}{lcccccc}
\hline Items & $\mathrm{SiO}_{2}$ & $\mathrm{Al}_{2} \mathrm{O}_{3}$ & $\mathrm{Fe}_{2} \mathrm{O}_{3}$ & $\mathrm{~K}_{2} \mathrm{O}$ & $\mathrm{CaO}$ & $\mathrm{MgO}$ \\
\hline Lake Hulun & 77.14 & 11.56 & 1.07 & 4.38 & 0.68 \\
Lake Taihu & 64.53 & 15.56 & 4.83 & 2.09 & 1.345 & 1.18 \\
\hline Items & $\mathrm{Na}_{2} \mathrm{O}$ & $\mathrm{TiO}_{2}$ & $\mathrm{P}_{2} \mathrm{O}_{5}$ & $\mathrm{SO}_{3}$ & $\mathrm{MnO}$ & 0.99 \\
\hline Lake Hulun & 1.99 & 0.31 & 0.06 & 0.18 & 0.025 \\
Lake Taihu & 0.82 & 0.77 & 0.24 & 0.25 & 0.08 & 8.54 \\
\hline
\end{tabular}

concentrations of $0.133 \mathrm{mg} / \mathrm{L}$ in 1995 for one peak and $0.097 \mathrm{mg} / \mathrm{L}$ in 2006 for the other peak, Fig. 5).

Two types of eutrophication and the corresponding aqueous nitrogen and phosphorus criteria/standards

Although both Lake Hulun and Lake Taihu have been suffering from cyanobacterial bloom in the recent years $(\mathrm{Li}$ et al. 2008; Qin et al. 2004a, b, 2007; Xie 2008; Zhu et al. 2008), eutrophication of the former lake was dominated by natural factors, such as atmospheric temperature, monsoon, the climatic drying and warming, and so on while the influences of anthropogenic actives plays a dominant role in the latter. Therefore, the current $\mathrm{N}$ and $\mathrm{P}$ criteria and standard of these two lakes should also be different. For Lake Hulun, the current $\mathrm{N}$ and $\mathrm{P}$ criteria are dependent on the historical nutrients levels mostly because of the uncertainties about natural effects, and the lower $25 \%$ of TN and TP levels were identified as the corresponding criteria, with the concentrations of $0.95 \mathrm{mg} / \mathrm{L} \mathrm{TN}$ and $0.08 \mathrm{mg} / \mathrm{L}$ TP (United States Environmental Protection Agency 2000). Meanwhile, the nutrients control standards were suggested as $1.98 \mathrm{mg} / \mathrm{L}$ for $\mathrm{TN}$ and $0.20 \mathrm{mg} / \mathrm{L}$ for TP when the value of TSI $\left(\sum\right)$ was 50 according to the Carlson's eutrophication model (Carlson 1977). As for Lake Taihu, $0.65 \mathrm{mg} / \mathrm{L}$ for TN and $0.03 \mathrm{mg} / \mathrm{L}$ for TP were adopted for nutrients criteria when TSI $\left(\sum\right)$ was 30 , and more rigorous $\mathrm{N}$ and $\mathrm{P}$ standards $(1.65 \mathrm{mg} / \mathrm{L}$ for $\mathrm{TN}$ and $0.06 \mathrm{mg} / \mathrm{L}$ for TP) were proposed by combining Carlson's eutrophication model with the lower $25 \%$ from 1987 to 2009. Therefore, The control nutrients inputs of lake water bodies were differed in the discriminative ecological regions, and the relative higher values of $\mathrm{N}$ and $\mathrm{P}$ criteria and the control standards were admitted in Lake Hulun while the relative lower values of $\mathrm{N}$ and $\mathrm{P}$ criteria and the control standards should be formulated for Lake Taihu.

\section{Conclusion}

The $\mathrm{N}$ and $\mathrm{P}$ status were compared in Lake Hulun and Lake Taihu, two shallow large eutrophic lakes in northern and southern China. Different factors influencing $\mathrm{N}$ and $\mathrm{P}$ levels in both lakes were further discussed. The $\mathrm{N}$ and $\mathrm{P}$ concentrations were much higher in Lake Hulun than that in Lake Taihu. Several uncontrolled natural factors, such as the climatic warming and the decrease of inflows/outflows water quantities were the main reasons for the decreased water volumes in Lake Hulun, which further led to the remarkable increase in $\mathrm{N}$ and $\mathrm{P}$ levels by inspissation as well as the decrease of aquatic production. However, anthropogenic activities, including high population densities, the rapid agricultural and industrial development in Lake Taihu drainage, accounted mainly for the high $\mathrm{N}$ and $\mathrm{P}$ levels in Lake Taihu. In addition, the larger specific area of sediment from Lake Taihu increased their nutrient adsorption capacity and thus served as an important nutrient sink. It was the lower temperature in Hulunbier Grassland that led to lower cyanobacterial densities and the shorter breakout period in summer despite of its higher concentrations of $\mathrm{N}$ and $\mathrm{P}$. However, the relatively lower $\mathrm{N}$ and $\mathrm{P}$ levels in Lake Taihu caused by anthropogenic activities, resulted in much higher primary productivity in water ecosystems because of higher temperature in summer. Therefore, the more rigorous $\mathrm{N}$ and $\mathrm{P}$ criteria and control standards should be formulated for Lake Taihu while the relative higher $\mathrm{N}$ and $\mathrm{P}$ levels should be considered in modifying of the nutrients' criteria and control standards of Lake Hulun.

Acknowledgments This work is supported by grants from National Special Program of Water Environment (2009ZX07106-001-002), National Basic Research Program of China (2008CB418102), National Natural Science Foundation of China (40865005), State Key Laboratory Program and the Crossed Program of Nanjing University (PCRRK2008007).

\section{References}

Anderson DM, Glibert PM, Burkholder JM (2002) Harmful algal blooms and eutrophication: nutrient sources, composition, and consequences. Estuaries 25:704-726

APHA AWWA, WPCF (1995) Standard methods for the examination of water and waste water, 19th edn. American Public Health Association, Washington, DC 
Asaeda T, Trung VK, Manatunge J (2000) Modeling the effects of macrophyte growth and decomposition on the nutrient budget in Shallow Lakes. Aquat Bot 68:217-237

Bai XL, Ding SM, Fan CX, Liu T, Shi D, Zhang L (2009) Organic phosphorus species in surface sediments of a large, shallow, eutrophic lake, Lake Taihu, China. Environ Pollut 157:2507-2513

Carlson RE (1977) A trophic state index for lakes. Limnol Oceanogr 22(2):361-369. http://www.jstor.org/discover/10.2307/2834910? uid $=3737800 \&$ uid $=2 \&$ uid $=4 \&$ sid $=47698827209377$

Chakrabarty D, Das SK (2006) Utilization and flow of energy in tropical ecosystem: A test case for two Ox-bow lakes. Int $\mathbf{J}$ Environ Sci Tech 3(2):141-146

Chen CC (2009) Environmental impact assessment framework by intefrating scientific analysis and subjective perception. Int $\mathbf{J}$ Environ Sci Tech 6(4):605-618

Chuai XM, Ding W, Chen XF, Wang XL, Miao AJ, Xi BD, He LS, Yang LY (2011) Phosphorus release from cyanobacterial blooms in Meiliang Bay of Lake Taihu, China. Ecol Eng 37(6):842-849

Environmental Protection Administration of China $<$ Monitoring method of water and wastewater $>$ editor committee, (2002). Monitoring method of water and wastewater, 4th edn. Chinese Environmental Science Press, Being, pp 266-281 (in Chinese)

Guo L (2007) Doing battle with the green monster of Taihu Lake. Science 317:1166

Guo HY, Wang XR, Zhu GJ (2004) Quantification and index of nonpoint source pollution in Lake Taihu region with GIS. Environ Geochem Health 26:147-156

Han XH, Yang C (2002) An analysis of the self-purification function of Hulun Lake and its effect on regional environmental conservation. J Nat Res 17(6):684-690 (in Chinese). http://d. wanfangdata.com.cn/Periodical_zrzyxb200206005.aspx

Havens KE (2003) Phosphorus-algal bloom relationships in large lakes of south Florida: Implication for establishing nutrient criteria. Lake Reserv Manag 19(3):222-228

Havens KE (2008) Cyanobacteria blooms: effects on aquatic ecosystems. Adv Exp Med Biol 619:733-747. doi:10.1007/978-0387-75865-7_33

He J, Gu XH, Liu GF (2008) Aquatic macrophytes in East Lake Taihu and its interaction with water environment. J Lake Sci 20(6):790-795 (in Chinese)

Heiskary S, Wilson B (2008) Minnesota's approach to lake nutrient criteria development. Lake Reserv Manag 24:282-297

Hu WP, Zhai SJ, Zhu ZC, Han HJ (2008) Impacts of the Yangtze River water transfer on restoration of Lake Taihu. Ecol Eng 34:30-49

Huang JX, Xu ZX (2009) Spatial-temporal characteristics of longterm trends for climate change in the Taihu Basin during 1954 to 2006. Resour Environ Yangtze Bain 18(1):33-40

James RT, Havens K, Zhu GW, Qin BQ (2009) Comparative analysis of nutrients, chlorophyll and transparency in two large shallow lakes (Lake Taihu, P. R. China and Lake Okeechobee, USA). Hydrobiologia 627:211-231

Jeppesen E, Jensen JP, Søndergaard M, Hansen KS, Møller PH, Rasmussen HU, Norby V, Larsen S (2003) Does resuspension prevent a shift to a clear state in shallow lakes during reoligotrophication. Limnol Oceanogr 48(5):1913-1919

Jin XC, Tu QY (1990) Standard methods for observation and analysis of lake eutrophication, 2nd edn. Chinese Environmental Science Press, Being, pp 178-215

Jones JR, Knowlton MF, Obrecht DV (2008) Roles of land cover and hydrology in determining nutrients in mid-continent reservoirs: implications for nutrient criteria and management. Lake Reserv Manag 24:1-9

Kangur K, Mols T (2008) Changes in spatial distribution of phosphorus and nitrogen in the large north-temperature lowland Lake Peipsi (Estonia/Russia). Hydrobiologia 599:31-39
Khemiri S, Chenini I (2009) Evaluation of ground water quality using multiple linear regression and structural equation modeling. Int $\mathbf{J}$ Environ Sci Tech 6(3):509-519

Le C, Zha Y, Li Y, Sun D, Lu H, Yin B (2010) Eutrophication of lake waters in China: cost, causes and control. Environ Manag 45:662-668

Li T, Wang DS, Zhang B, Liu HJ, Tang HX (2006) Characterization of the phosphate adsorption and morphology of sediment particles under simulative disturbing conditions. J Hazard Mater 137:1624-1630

Li ZJ, Zhang ZB, Jiang FY, Wang SW, Wang FJ (2008) Lake Hulun Chi (continuous Chi two). Neimenggu Culture press, Nimenggu

Liu ES, Bao CH, Cao P, Ding SQ (2006) Analysis on the correlation between the catch of ice fish and main fishes in Lake Taihu. J Anhui Agric Univ 33(1):70-75 (in Chinese)

Maemets H, Palmik K, Haldna M, Sudnitsyna D, Melnik M (2010) Eutrophication and macrophyte species richness in the large shallow North-European Lake Peipsi. Aquat Bot 92(4):273-280

Mahmood Q, Hu BL, Cai J, Zheng P, Azim MR, Jilani G, Islam E (2009) Isolation of Ochrobactrum sp. QZ2 from sulfide and nitrite treatment system. J Hazard Mater 165:558-565

Marotta H, Duarte CM, Meirelles-Pereira F, Bento L, Esteves FA, Enrich-Prast A (2010) Long-term $\mathrm{CO}_{2}$ variability in two shallow tropical lakes experiencing episodic eutrophication and acidification events. Ecosystem 13(3):382-392

McCarthy MJ, Lavrentyev PJ, Yang LY, Zhang L, Chen YW, Qin BQ, Gardner WS (2007) Nitrogen dynamics and microbial food web structure during a summer cyanobacterial bloom in a subtropical, shallow, well-mixed, eutrophic lake (Lake Taihu, China). Hydrobiologia 581:195-207

McCarthy MJ, James RT, Chen YW, East TL, Gardner WS (2009) Nutrient ratios and phytoplankton community structure in the large, shallow, eutrophic, subtropical Lakes Okeechobee (Florida, USA) and Taihu (China). Limnol 10:215-227

Pearl HW, Hall NS, Calandrino ES (2011) Controlling harmful cyanobacterial blooms in a world experiencing anthropogenic and climatic-induced change. Sci Total Environ 409(10): 1739-1745. doi:10.1016/j.scitotenv.2011.02.001

Qin BQ (2009) Lake eutrophication: control countermeasures and recycling exploitation. Ecol Eng 35:1569-1573

Qin BQ, Hu WP, Gao G, Luo LC, Zhang JS (2004a) Dynamic of sediment resuspension and the conceptual schema of nutrient release in the large shallow Lake Taihu, China. Chin Sci Bull 49(1):54-64

Qin BQ, Hu WP, Chen WM (2004b) The evolution process and mechanism of water environment in Lake Taihu. Science Press, Beijing

Qin BQ, Xu PZ, Wu QL, Luo LC, Zhang YL (2007) Environmental issues of Lake Taihu, China. Hydrobiologia 581:3-14

Reckhow KH, Arhonditsis GB, Kenney MA, Hauser L, Tribo J, Wu C, Elcock KJ, Steinberg LJ, Stow CA, Mcbride SJ (2005) A predictive approach to nutrient criteria. Environ Sci Technol 39(9):2913-1919

Song XL, Liu ZW, Yang GJ, Chen YW (2010) Effects of resuspension and eutrophication level on summer phytoplankton dynamics in two hypertrophic areas of Lake Taihu, China. Aquat Ecol 44(1):41-54

Soranno PA, Cheruvelil KS, Stevenson RJ, Rollins SL, Holden SW, Heaton S, Torng E (2008) A framework for developing ecosystem-specific nutrient criteria: Integrating biological thresholds with predictive modeling. Limnol Oceanogr 53(2): 773-787

Tuomainen JM, Hietanen S, Kuparinen J, Martikainen PJ, Servomaa K (2003) Baltic Sea cyanobacterial bloom contains denitrification and nitrification genes, but has negligible denitrification. FEMS Microbiol Ecol 45:83-96 
United States Environmental Protection Agency (2000) Nutrient Criteria technical guidance manual, lakes and reservoirs, 1st edn. Washington DC

Wang LH (2006) Analysis on the aquatic environment and water quality condition of Lake Hulun. J. Hulunbeier Coll 14(6):5-7 (in Chinese)

Wang SR, Jin XC, Pan Y, Zhao HC, Zhou XN, Wu FC (2005) Phosphorus fractions and phosphate sorption characteristics in relation to the sediment compositions of shallow lakes in the middle and lower reaches of Yangtze River region, China. Colloid Interface Sci 28:339-346

Xie P (2008) Historical development of cyanobacteria with bloom disaster in Lake Taihu. Science Press, Beijing

Xie L, Xie P, Guo L, Li L, Miyabara Y, Park HD (2005) Organ distribution and bioaccumulation of microcystins in freshwater fish at different trophic levels from the eutrophic Lake Chaohu, China. Environ Toxicol 20:293-300. doi:10.1002/tox.20120

Xu H, Yang LZ, Zhao GM, Jiao JG, Yin SX, Liu ZP (2009) Anthropogenic impact on surface water quality in Taihu Lake region, China. Pedosphere 19(6):765-778

Xu H, Paerl HW, Qin BQ, Zhu GW, Gao G (2010) Nitrogen and phosphorus inputs control phytoplankton growth in eutrophic Lake Taihu, China. Limnol Oceanogr 55(1):420-432

Xue B, Wang WC, Wang SM, Ma Y, Dickman MD (2003) Lake level changes documented by sediment properties and diatom of Hulun Lake, China since the late Glacial. Hydrobiologia 498:133-141
Yang LY, Qin BQ, Hu WP, Luo LC, Song YZ (2007) The atmospheric deposition of nitrogen and phosphorus nutrients in Taihu Lake. Oceanol Et Limnol Sinica 38(2):104-110

Yuan LN, Zhu W, Xiao L, Yang LY (2009) Phosphorus cycling between the colonial cyanobacterium Microcysits aeruginosa and attached bacteria, Pseudomonas. Aquat Ecol 43(3):859-866

Zhai SJ, Yang LY, Hu WP (2009) Observations of atmospheric nitrogen and phosphorus deposition during the period of algal bloom formation in Northern Lake Taihu, China. Environ Manag $4: 542-551$

Zhao HY, Li CC, Zhao HH, Tian HC, Song QW, Dou ZQ (2007) The climate change and its effect on the water environment in the Hulun Lake Wetland. J. Glaciol Geocryol 29(5):795-801

Zhao DY, Ma T, Zeng J, Yan WM, Jiang CL, Feng JW, Xu YN, Zhao HZ (2011) Phospholipid fatty acids analysis of vertical distribution of microbial communities in eutrophic lake sediments. Int J Environ Sci Tech 8(3):571-580

Zhou AM, Tang HX, Wang DS (2005) Phosphorus adsorption on natural sediments: Modeling and effects of $\mathrm{pH}$ and sediment composition. Water Res 39:1245-1254

Zhu GW, Qin BQ, Gao G (2005) Direct evidence of phosphorus out break release from sediment to overlying water in a large shallow lake caused by strong wind wave disturbance. Chin Sci Bull 50(6):577-582

Zhu GW, Wang F, Gao G, Zhang YL (2008) Variability of phosphorus concentration in large, shallow and eutrophic Lake Taihu, China. Water Environ Res 80(9):832-839 